Copyright (C) 2021 University of Bucharest Printed in Romania. All rights reserved

ISSN print: $1224-5984$

ISSN online: $2248-3942$
Rom Biotechnol Lett. 2021; 26(4): 2846-2854 doi: $10.25083 / \mathrm{rbl} / 26.4 / 2846-2854$

Received for publication, November, 22, 2020

Accepted, May, 10, 2021

Original paper

\title{
Balady bread; A comprehensive study on sensory, chemical and rheological properties during fortification by Quinoa /Chenopodium quinoa Willd.)
}

\author{
NAHLA A.F. ${ }^{1,2}$, BADAWY W.Z. ${ }^{1}$, EL-BANA M.A. ${ }^{2}$, KASSAB H.A. ${ }^{1}$ \\ ${ }^{1}$ Food Technology Department, Faculty of Agriculture, Kafrelsheikh University, Egypt \\ ${ }^{2}$ Food Technology Department, Food Technology. Research. Institute, Agricultural Research \\ Center, Giza, Egypt
}

\begin{abstract}
Quinoa is recently gaining more interest from many countries as a nutritious substitute and food addition. Proximate chemical analysis of quinoa flour (QF) was estimated. Additionally, the rheological properties of balady bread dough fortified with QF were evaluated. It was found that $\mathrm{QF}$ was an ideal source of minerals especially potassium $(808.7 \mathrm{mg} / 100 \mathrm{~g})$ and essential amino acids compared with wheat flour. Moreover, the protein content of bread substituted with QF increased by increasing QF content. Also, the sensory properties of bread were acceptable. There was no noticeable difference $(P \leq 0.05)$ between bread fortified with $10 \%$ and control sample. The gluten levels went down by raising the levels of QF from 10 to $40 \%$ whilst; the protein content increased from 10 to $40 \%$ by rising QF replacement levels. The obtained date suggested that QF could be utilized as fortifying source of protein and nutrients especially, in bakery products.
\end{abstract}

Keywords Quinoa flour, Balady Bread, Nutritional parameters.

To cite this article: NAHLA, A.F., BADAWY, W.Z., EL-BANA, M.A., KASSAB, H.A. Balady bread: A comprehensive study on sensory, chemical and rheological properties during fortification by Quinoa (Chenopodium quinoa Willd.). Rom Biotechnol Lett. 2021; 26(4): 2846-2854. DOI: $10.25083 / \mathrm{rbl} / 26.4 / 2846-2854$

*Corresponding author: NAHLA, A.F., Food Technology Department, Food Technology. Research. Institute, Agricultural Research Center, 9 Algamaa street, Giza, Egypt, Tel.: 35718324, 35735090, 35718326, 35718328, Fax: 35684669

E-mail: ftri@arc.sci.eg 


\section{Introduction}

Quinoa (Chenopodium quinoa Willd.) is a pseudo cereal which had been cultivated in South America as an essential food item for thousands of years. Recently, quinoa attracted attention of the world, because of its great flexibility of different cultivation conditions and its multiple uses, also the high nutritional values (ABDERRAHIM \& al, [1]; JAMES [2]; WANG \& ZHU [3]).

Many countries now having more production of quinoa seed with a great technological and commercial interest for human. It has good nutritional alternatives for animals as well as in pharmaceuticals (REPO-CARRASCO \& al, [4]; BHARGAVA \& al, [5]; GELY \& SANTALLA, [6]).

Quinoa has high protein content and excellent essential amino acid profile, because of a wider amino acid spectrum than that of cereal and legumes, with higher lysine and methionine contents. As quinoa seeds have high quality proteins and higher levels of energy, calcium, phosphorus, magnesium, iron, fiber, and B-vitamins than barley, oats, rice, corn or wheat (DINI \& al, [7]; COMAI $\&$ al, [8]).

In comparison of most cereals, quinoa seeds have a higher nutritional value (MATIACEVICH \& al, [9]). The protein content of quinoa seeds varies from $8 \%$ to $22 \%$, which is higher than that in common cereals but it contains less than $50 \%$ of the protein content found in most legumes. Most of Quinoa protein is located in the embryo. Moreover, quinoa is an ideal source with albumins and globulins are the major protein content (44-77\% of total protein), while prolamins are $(0.5-7.0 \%)$, which is greater than that of prolamins $(0.5-7.0 \%)$. Quinoa is considered to be a gluten-free grain because it contains very little or no prolamin. It provides a nutritional, economical, easyto-prepare, flavorful food source which is of particular relevance for people with gluten intolerance, such as those with celiac disease (FAIRWEATHER-TAIT \& al, [10]).

The seeds are used to make different food products including bread, biscuits, cookies, crepes, muffins, pancakes, and tortillas. More recently attention, has been given to quinoa for people suffering celiac disease (allergy to gluten), as an alternative to wheat, rye and barley, which all contain gluten (JACOBSEN [11]; JACOBSEN [12]).

Quinoa flour (QF) can be mixed with maize or wheat flour. Several levels of QF substitution have been reported, for instance, in bread (10-13\% QF), noodles and pasta $(30-40 \% \mathrm{QF})$, and sweet biscuits (60\% QF) (FAIRWEATHER-TAIT \& al, [10]; BHARGAVA \& al, [5]).

Balady bread as a main food provides about $78 \%$ calories and $60 \%$ protein of the total intake. In addition, among the poor classes about $90 \%$ of the total calories are derived from bread and cereals (CAPMS, [13]). Also, in Egypt bread is the major food which consumed by people in all socioeconomic levels, it resembles nearly two third of the protein available and about $70 \%$ of calories (IBRAHIM \& al, [14]).

The objective of this study is to evaluate the nutritional value of quinoa seeds which are being grown in Egypt. Moreover, to evaluate the sensory properties of balady bread prepared using different levels of quinoa flour as an alternative of wheat flour (WF). Additionally, the characteristics of the fortified dough were evaluated by rheological tests.

\section{Materials and Methods}

\section{Materials and reagents}

Quinoa seeds were taken from Desert Research Center in Cairo, Egypt in 2015 season at the recommended conditions of time of culture, fertilization, harvesting time and irrigation. WF (82\% extraction) was taken from the North Cairo Flour Mills Company, Egypt. All chemical used in this investigation were obtained from Gomhoria company for chemicals, Egypt.

\section{Methods}

\subsection{Preparation of $Q F$}

Quinoa seeds were washed many times by cold water to eliminate saponins until disappearing of foam in the washing water, and then dried at $50^{\circ} \mathrm{C}$. The quinoa seeds were ground to fine powder in stainless steel electric grinder using a Laboratorial disc mill into flour to get QF which can go through a 60-80 mesh screen (ABOUZAID \& al, [15]).

\subsubsection{Chemical composition of samples}

Moisture, crude protein ( $\mathrm{N}$ x 6.25), fat content, ash and crude fibers of samples were determined according to the method described in ASSOCIATION OF OFFICIAL ANALYTICAL CHEMISTRY, [16]. Total carbohydrates were calculated by differences.

\subsubsection{Minerals content}

Calcium $(\mathrm{Ca})$, magnesium $(\mathrm{Mg})$, iron $(\mathrm{Fe})$, copper $(\mathrm{Cu})$, zink $(\mathrm{Zn})$ and manganese $(\mathrm{Mn})$ of quinoa flour and balady bread were calculated by the method stated by PEARSON [17] using atomic absorption spectrophotometer (Perkin Elmer Model 4100 ZL), while sodium $(\mathrm{Na})$ and potassium $(\mathrm{K})$ were determined using flame photometer. As for phosphorus (P) we determine it by ascorbic acid technique using the colorimetric method (MURPHY \& RILEY, [18]).

\subsubsection{Amino acids content of $Q F$ and $W F$}

The amino acids contents were determined using Beackman amino acid analyzer according to the method of SADASIVAM \& MANICKAM, [19]. Tryptophan content has been determined colorimetrically after going through to alkaline hydrolysis as outlined by MILLER, [20].

\subsection{Preparation of flour blends}

WF was blended well with the QF and gum Arabic as enhancer for gluten network at different replacement levels. Whilst, the control sample was prepared without gum Arabic as seen in Table 1. 
Table 1. Flour blends used in balady bread making

\begin{tabular}{|c|c|c|c|}
\hline $\begin{array}{c}\text { Sample blends } \\
\text { number }\end{array}$ & WF & QF & Gum Arabic \\
\hline 1 & 100 & - & - \\
2 & 89 & 10 & 1 \\
3 & 79 & 20 & 1 \\
4 & 69 & 30 & 1 \\
5 & 59 & 40 & 1 \\
\hline
\end{tabular}

\subsubsection{Rheological and extensograph properties}

The rheological properties of dough blends were analyzed by using farinograph and extensograph according to AMERICAN ASSOCIATION OF CEREAL CHEMISTRY, [21].

\subsubsection{Preparation of balady bread}

Balady bread was made using the method stated in EL-FARRA \& al, [22]. Balady bread blends were developed by replacing a part of WF with different levels $(10,20,30$ and $40 \%)$ of QF and $1 \%$ gum Arabic.

2.2.3. Organoleptic properties of balady bread

The sensory evaluation was done by 24 panelists according to EL-FARRA \& al, [22] with slight modifications. The judges were told to give a score from 0 to 10 for color, taste, odor and texture for prepared samples. The overall acceptability was estimated depending on all parameters values.

2.2.4. Gluten content of the dough

Gluten was obtained from the dough using gluten washing apparatus using AMERICAN ASSOCIATION OF CEREAL CHEMISTRY, [21].

\section{Statistical analysis}

Most of that received data were analyzed statistically using the analysis of variances and the means which were tested using the least significant difference test (LSD) as outlined by STEELL \& TORRIE, [23].

\section{Results and Discussions}

\section{Proximate chemical composition of quinoa and WF}

The obtained results in Figure 1 indicate that, QF had significantly higher contents of crude protein, fat content, ash and crude fiber $(13.49 \%, 4.62 \%, 7.81 \%$ and $2.43 \%$ respectively) in comparison of WF. The results were in the same trend of those obtained by JANCUROVÁ \& al, [24] who stated that QF contains high amount of crude protein, fat content, ash and all dietary fiber in comparison to WF. Whilst, WF contains higher amount of total carbohydrate $84.79 \%$ than QF which has $71.65 \%$. The obtained results were in the agreement with those reported by BLASCO LAMENCA, [25]; HAREEDYLOBNA \& al, [26].

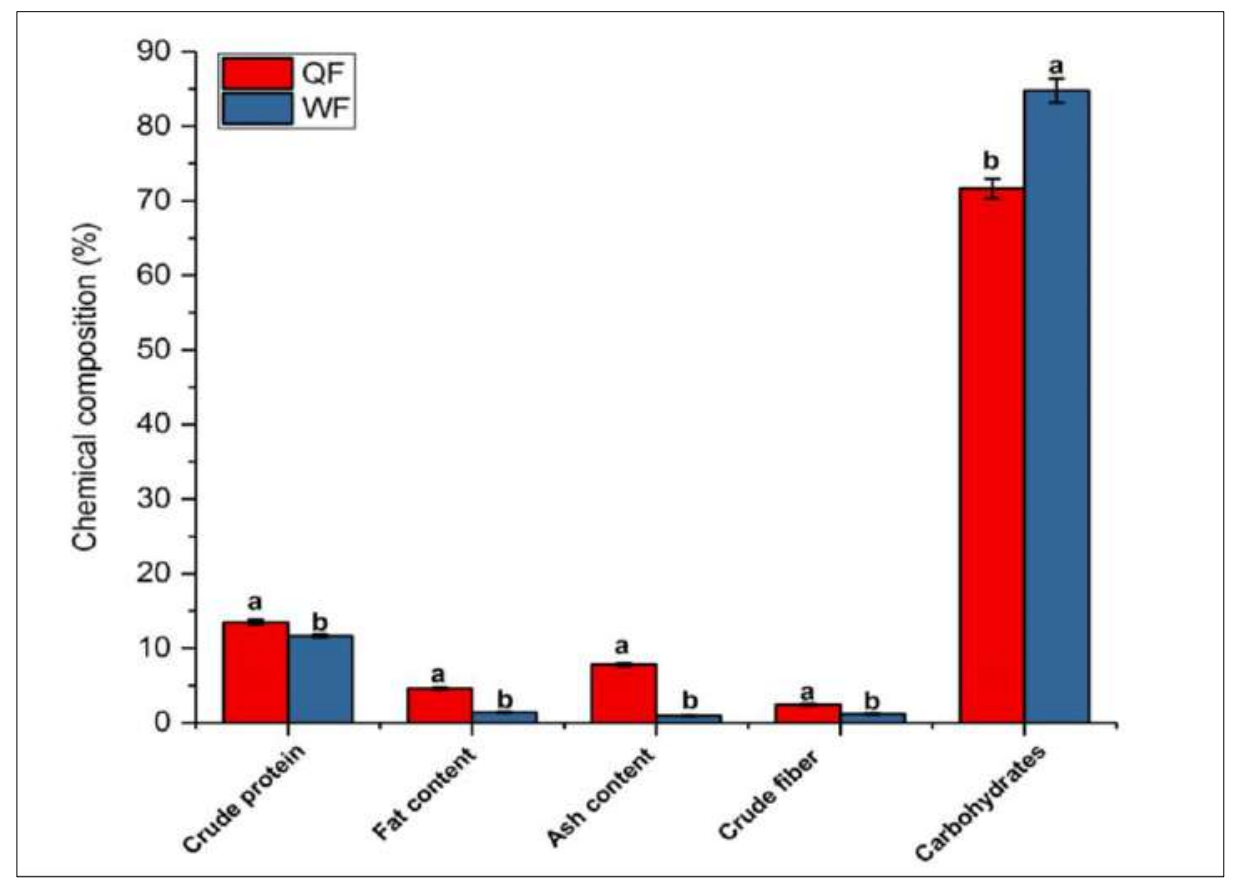

Figure 1. Chemical composition of QF and WF. Each value was an average of three determinations. Values followed by the same letter in column are not significantly different at $p<0.05$. 


\section{Minerals content}

Minerals and elements are essential for human nutrition, some are important as a component in producing hemoglobin in blood. Magnesium and manganese are for activation of enzymes and stimulating insulin a. Calcium and phosphorus are crucial for bones and some of those are very important for supporting vitamins action. Potassium is very important for cardiovascular function and zinc helps control blood sugar levels (NATIONAL ACADEMY OF SCIENCES, [27]).
Results of minerals composition of QF and WF are reported in Table 2, the data showed that QF contained higher values in all mentioned elements except of $\mathrm{Mn}$ which was higher in WF. Also, QF is very rich in $\mathrm{K}(881 \mathrm{mg} / 100 \mathrm{~g})$. The Fe content of QF is higher eight times than that of WF. The Fe is important for children to avoid anemia especially in developing countries. The results indicated that $\mathrm{QF}$ was a great source of minerals. The results were in the same trend of those reported by Hareedylobna \& al, [26]; Bhargava \& al, [5].

Table 2. Minerals content of QF and WF (mg/100 g).

\begin{tabular}{|c|c|c|c|c|c|c|c|c|c|}
\hline \multirow{2}{*}{ Samples } & \multicolumn{9}{|c|}{ Minerals (mg/100 g) } \\
\hline & $\mathrm{P}$ & $\mathrm{K}$ & $\mathrm{Na}$ & $\mathrm{Ca}$ & $\mathrm{Mg}$ & $\mathrm{Fe}$ & $\mathrm{Mn}$ & $\mathrm{Cu}$ & $\mathrm{Zn}$ \\
\hline $\mathrm{QF}$ & 414 & 881 & 85.7 & 130.4 & 198.6 & 13.2 & 0.26 & 1.86 & 0.95 \\
\hline WF & 141.8 & 130.2 & 33.2 & 36.2 & $130.6 b$ & 1.56 & 0.90 & 0.37 & 0.77 \\
\hline
\end{tabular}

\section{Amino acids composition}

The essential and non-essential amino acids profile for quinoa and WF are cleared in Tables 3. The results revealed that the essential amino acids of QF were $4.20 \%$, $1.95 \%, 4.80 \%, 3.20 \%$ and $1.14 \%$ for valine, methionine, lysine, threonine and tryptophan, respectively. These values were higher than those of WF. Results in this respect were recorded by GESINSKI \& NOWAK, [28].
On the other hand, QF contained higher amount of nonessential amino acids except of proline which was higher in WF. Also, from the same Table; found that amino acids content of QF were higher than those of WF. These results are matches with those obtained by HAREEDYLOBNA \& al, [26]; JAMES, [2] who indicated that, histidine content of quinoa proteins was higher than barley, soy, or wheat proteins.

Table 3. Amino acids composition of QF and WF protein (g/100 g protein)

\begin{tabular}{|c|c|c|c|c|c|}
\hline Essential amino acids & $\begin{array}{l}\mathrm{QF} \\
(\%)\end{array}$ & $\begin{array}{l}\text { WF } \\
(\%)\end{array}$ & Non-essential amino acids & $\begin{array}{l}\mathrm{QF} \\
(\%)\end{array}$ & $\begin{array}{l}\text { WF } \\
(\%)\end{array}$ \\
\hline Valine & 4.20 & 3.90 & Arginine & 8.1 & 4.1 \\
\hline Methionine & 1.95 & 1.35 & Aspartic & 7.42 & 4.38 \\
\hline Isoleucine & 3.20 & 3.60 & Serine & 5.0 & 4.38 \\
\hline Leucine & 5.0 & 6.0 & Glutamic & 11.9 & 11.87 \\
\hline Tyrosine & 2.6 & 2.94 & Proline & 4.1 & 9.31 \\
\hline Phenylalanine & 3.20 & 4.50 & Glycine & 4.9 & 4.50 \\
\hline Lysine & 4.80 & 2.1 & Alanine & 3.90 & 3.10 \\
\hline Cystine & 1.73 & 2.78 & ND & ND & ND \\
\hline Hisitidine & 3.5 & 2.10 & ND & ND & ND \\
\hline Therionine & 3.2 & 2.3 & ND & ND & ND \\
\hline Tryptophan & 1.14 & 1.13 & ND & ND & ND \\
\hline $\begin{array}{c}\text { Total essential amino } \\
\text { acids }\end{array}$ & 34.66 & 32.7 & $\begin{array}{c}\text { Total non-essential amino } \\
\text { acids }\end{array}$ & 45.32 & 41.64 \\
\hline
\end{tabular}

Tryptophan was determined colorimetrically

ND: Not detected

\section{Rheological and Extensograph properties of different flour blends}

\subsection{Farinograph properties}

The Farinogram recognized the flour behavior during the bread making process. It shows the elasticity and plasticity of dough while undergoing continuous mixing at constant temperature (STIKIC \& al, [29]). The results in Figure 2 show the replacement impact of WF by various levels of 10, 20, 30 and $40 \%$ of QF with a stable amount from gum Arabic on Farinograph parameters. The obtained data proved that, water absorption percentage increases from $66.80 \%$ for the control sample $(100 \% \mathrm{WF})$ to 67.60 , $68.10,69.30$ and $70.0 \%$ at $10,20,30$ and $40 \%$ replacement, 
respectively. Arrival time and dough development time are stable at all ratios of replacement but they are higher than control. Results are matching with CHAUHAN \& al, [30]. Dough stability is dependent on the quantity and quality of dough gluten. The stability went down (4.0, 4.5, 4.0 and $3.5 \mathrm{~min}$ for $10,20,30$ and $40 \%$ respectively) compared to control (5.0 min). Results match with STIKIC
\& al, [29]; WAFAA \& SHAMS, [31] who reported that, the addition of QF did not change rheological properties of the dough and addition of $20 \%$ QF had an acceptable effect on the rheological characteristic of dough. Weakening value (BU) was increased as a result of adding of QF compared with control. This might be because of the higher fiber content of quinoa.
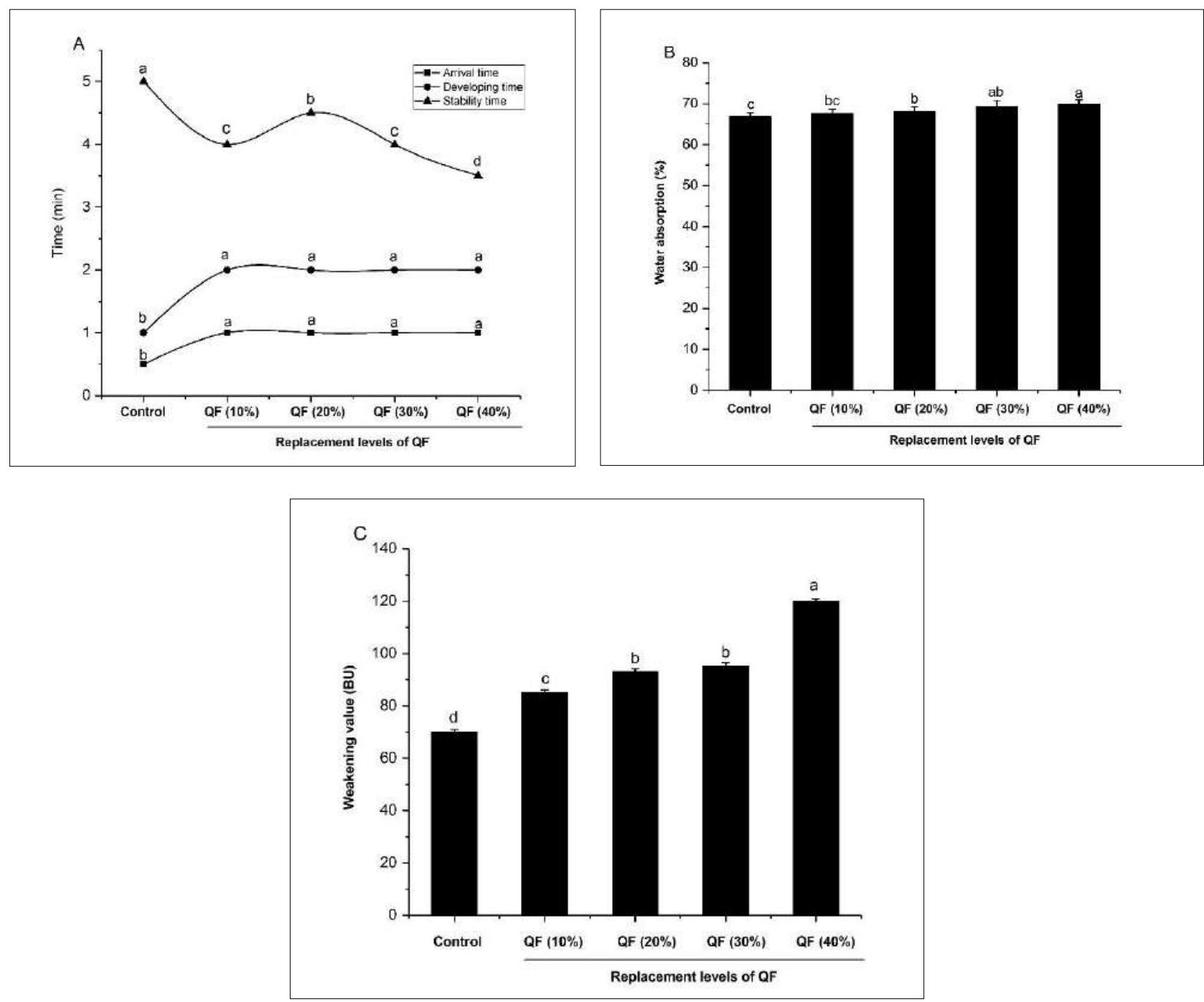

Figure 2. Effect of QF and gum Arabic partial replacement of WF on farinograph parameters: (A) arrival time, developing time and stability time. (B) water absorption. (C) stability time.

\subsection{Extensograph properties}

Extensograph gives information about dough's viscoelastic behavior. This equipment studies extensibility and extension resistance of the dough. A combination of good extensibility and good resistance results is required to dough property (WALKER \& HAZELTON, [32]). Data in Figure 3 showed the influence of QF at replacement levels $10,20,30$ and $40 \%$ to WF on extensograph parameters. The amount of gluten in dough affects on the resistance of extension (elasticity). The elasticity decreased significantly with the percentage increase of added QF.
The resistance to extension (elasticity) of blends decreased from 500 B.U. in control sample to 460, 320, 270 and 250 B.U. at replacement levels of QF 10, 20, 30 and 40\%, respectively. In contrast, due to gluten lake in QF (as gluten free) the elasticity decreased with an increase in QF. The extensibility of blends decreased from control to $40 \%$ of QF. No significant differences in the control (wheat dough), 10 and 20\% QF dough (120, 115 and 115 respectively) were observed, which gave higher extensibility values than other blends of QF, whereas the blends containing 30 and $40 \%$ QF showed the lowest 
values of the extensibility (110 and $105 \mathrm{~mm}$ ), respectively. The obtained results agreed with earlier study of ENRIQUEZ \& al, [33] who stated that addition of QF at ratio 5,10 , and $15 \%$ to $\mathrm{WF}$ reduced the extensibility significantly. They also observed a significant reduction in the extensibility due to the lack of gluten-like protein in QF. Proportional number of blends decreased from control (4.16) to (2.38) $40 \%$ of QF. In the same way, energy of blends decreased from control (68.0) to (36.0) $40 \% \mathrm{QF}$.
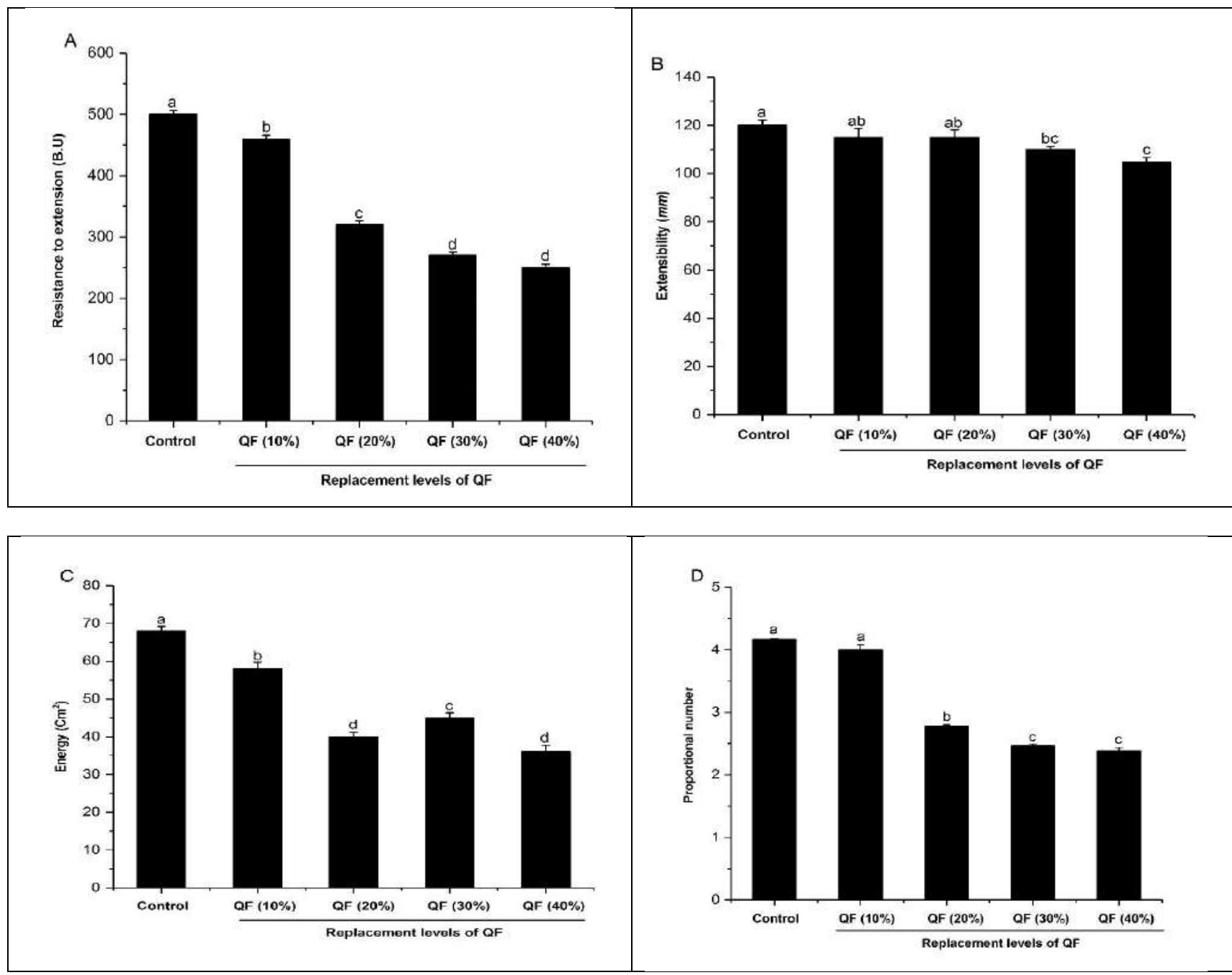

Figure 3. Effect of QF and gum Arabic addition as partial substitute to WF on the extensograph parameters: (A) resistance to extension. (B) extensibility. (C) Energy. (D) proportional number.

\section{Sensory evaluation of balady bread}

Figure 4 shows organoleptic characteristics of balady bread with different blends of WF, QF and gum Arabic at different levels (10, 20, 30 and 40\%) which states that balady bread produced from WF and blends of QF and gum Arabic at levels (10 and 20\%) had good values for (color, taste, odor, texture and overall acceptability). These results are matches with STIKIC \& al, [29] who stated that sensory characteristic of breads $(10,15$ and $20 \%$ QF) were acceptable even at $20 \%$ level, which was the highest level tested and also studied new form of quinoa presentation such as bread supplemented with quinoa can lead to development of a range of new baking products with enhanced nutritive value. Also results show that, balady bread prepared from blends 30 and $40 \%$ of QF causes a decrease in the previous parameters compared to control as they show that QF can be involved in producing balady bread which match with the reports by LORENZ \& COULTER, [34] who evaluated the performance of QF/WF blends (5/95, 10/90, 20/80 and $30 / 70 \%$ ) in breads, cakes and cookies. Bread baked with $5 \%$ and $10 \%$ of QF was of good quality. Loaf volume is less, crumb become more open and texture slightly harsh when we use more of QF. A better after taste was noticed at the $30 \%$ level. 


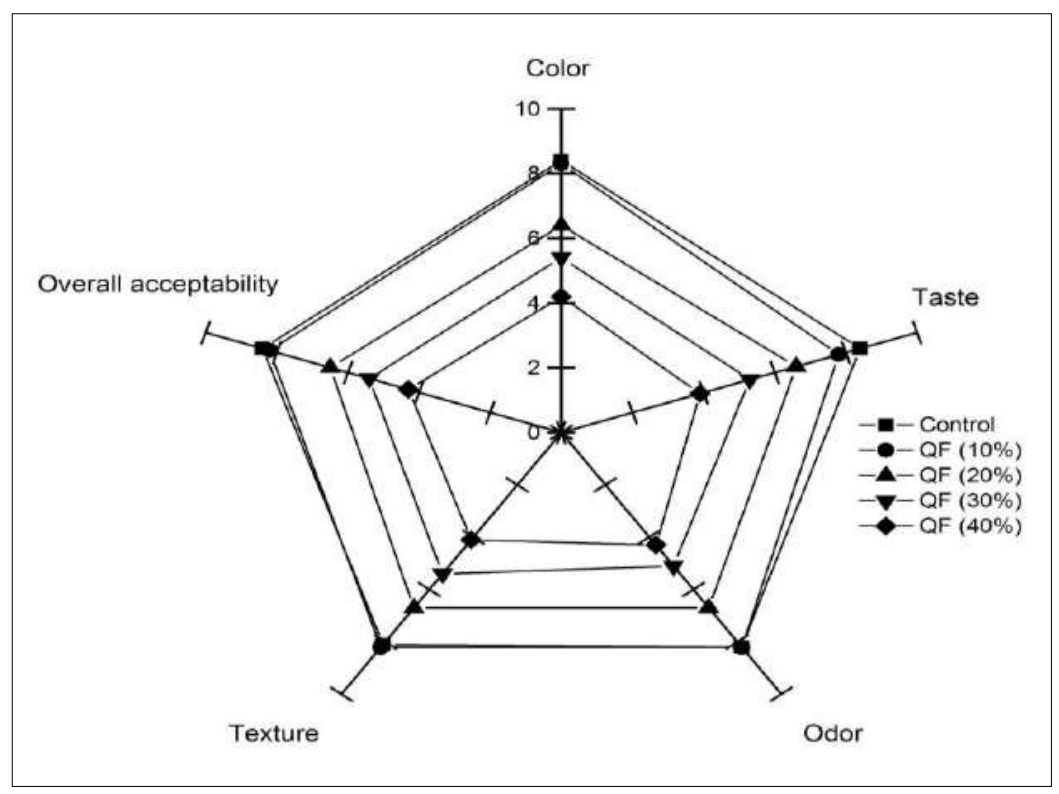

Figure 4. Hedonic sensory evaluation fortified Balady bread with QF at different levels.

\section{Gluten and protein content of balady bread}

In Figure 5 gluten and protein contents of balady bread which contains QF which show that gluten content went down when we increase the substitution levels of QF from 10 to $40 \%$. Therefore, quinoa contains very little to no prolamin, and is known to be a gluten-free grain and also, the protein content increased gradually with an improvement in the amount of the replacement levels for QF which matches with findings by STIKIC $\&$ al, [29].

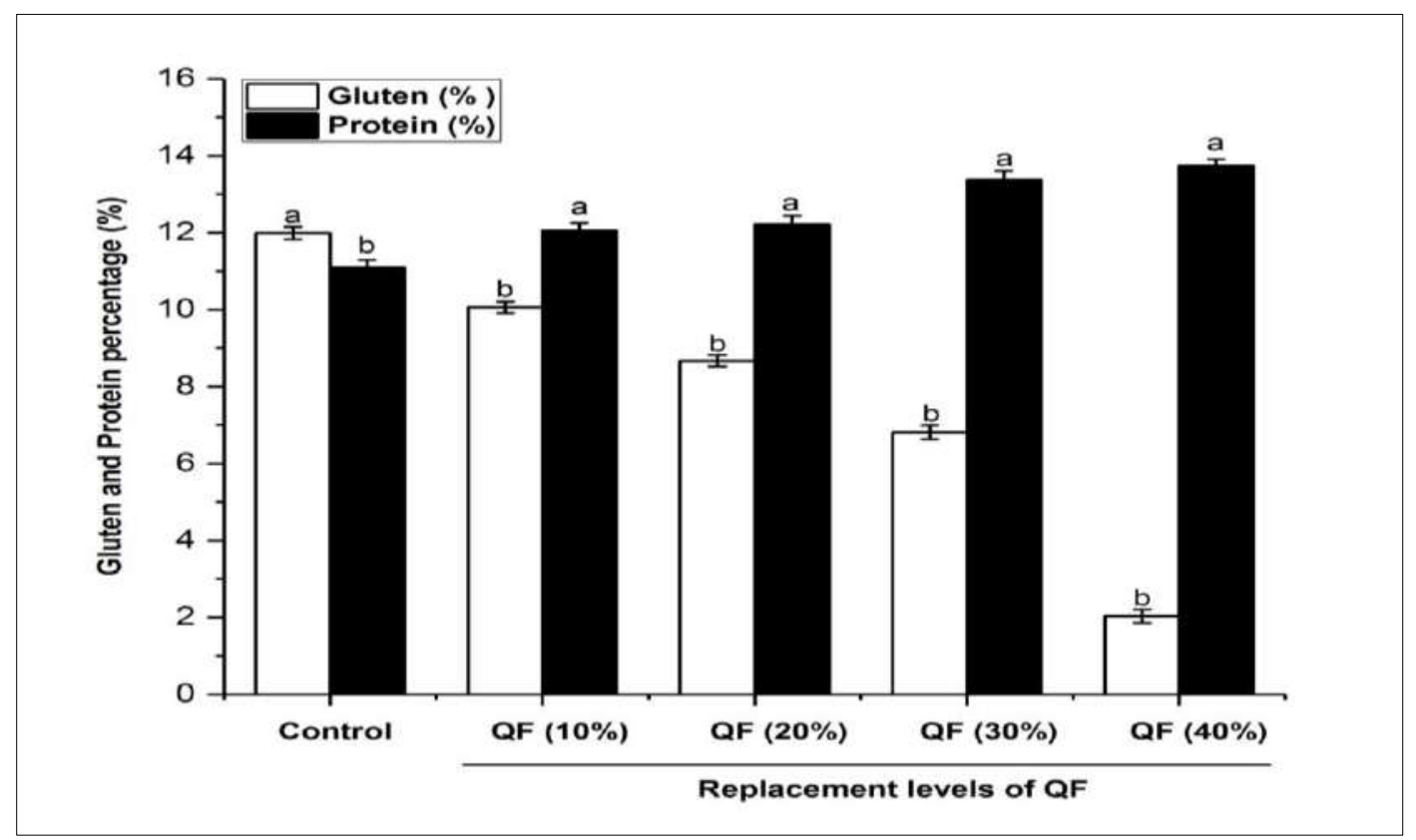

Figure 5. Influence of QF addition on gluten and protein contents of balady bread.

\section{Minerals content of balady bread processed with QF}

Table 4 shows that adding QF increased all minerals compared to control. Minerals content of balady bread increased by increasing replacement ratio, as a result addition of QF to WF ensures obtaining a satisfied balady bread rich in some important minerals such as phosphorus and potassium which somewhat in agreement with those reported by STIKIC \& al, [29]. 
Table 4. Influence of QF addition on minerals content of balady bread

\begin{tabular}{|c|c|c|c|c|c|c|c|c|}
\hline \multirow{2}{*}{ Samples } & \multicolumn{9}{|c|}{ Minerals $(\mathrm{mg} / \mathrm{L})$} \\
\cline { 2 - 9 } & $\mathrm{Fe}$ & $\mathrm{Mn}$ & $\mathrm{Na}$ & $\mathrm{Ca}$ & $\mathrm{K}$ & $\mathrm{Mg}$ & $\mathrm{Zn}$ & $\mathrm{P}$ \\
\hline Control & 2.12 & 0.42 & 75.02 & 11.00 & 64.5 & 29.00 & 1.79 & 46.08 \\
\hline $10 \%$ & 2.69 & 0.56 & 77.75 & 11.70 & 64.78 & 30.45 & 2.41 & 48.03 \\
\hline $20 \%$ & 2.95 & 0.71 & 79.0 & 12.48 & 68.35 & 32.63 & 3.07 & 50.14 \\
\hline $30 \%$ & 3.10 & 0.78 & 81.96 & 14.98 & 72.85 & 33.05 & 3.85 & 52.34 \\
\hline $40 \%$ & 3.25 & 0.81 & 83.75 & 16.87 & 74.55 & 33.95 & 4.06 & 53.77 \\
\hline
\end{tabular}

\section{Conclusion}

As shown in this research, the fortification of baked products like balady bread with QF by adding it to WF resulted in increased protein, ash, crude fiber and overall nutrients contents compared to WF alone. Higher protein content is because of most of essential amino acids of QF clearly were higher than that of WF and as was shown that protein content of balady bread fortified with $\mathrm{QF}$ increased by increasing the replacement levels from 10 to $40 \%$. In addition, an increasement in trace minerals content by increasing of QF percentage was observed. Additionally, more favorable results found that the gluten content decreased by rising the replacement levels of QF from 10 to $40 \%$ which is considered as healthier. On the other hand, the farinograph and extensograph parameters of dough improved which has favorable industrial applications. Furthermore, an improvement in taste, odor, color and texture were noticed which can have a satisfying commercial impact. Finally, it is concluded that $\mathrm{QF}$ is a better option as an addition to baked products from all perspectives.

\section{Acknowledgments}

The study was supported by a project funded by Kafrelshiekh University and Agriculture Research Center, Egypt.

\section{Conflicts of Interest}

The authors declare that there are no conflicts of interest.

\section{References}

1. F. ABDERRAHIM, E. HUANATICO, R. SEGURA, S. ARRIBAS, M. C. GONZALEZ, L. CONDEZOHOYOS. Physical features, phenolic compounds, betalains and total antioxidant capacity of coloured quinoa seeds (Chenopodium quinoa Willd.) from Peruvian Altiplano. Food Chemistry, 183, 83-90 (2015).

2. L.E. A. JAMES. Quinoa (Chenopodium quinoa Willd.): composition, chemistry, nutritional, and functional properties. Advances in food and nutrition research, 58, 1-31 (2009).

3. S. WANG, F. ZHU. Formulation and quality attributes of quinoa food products. Food and bioprocess technology, 9, 49-68 (2016).

4. R. REPO-CARRASCO, C. ESPINOZA, S.-E. JACOBSEN. Nutritional value and use of the Andean crops quinoa (Chenopodium quinoa) and kañiwa (Chenopodium pallidicaule). Food reviews international, 19, 179-189 (2003).

5. A. BHARGAVA, S. SHUKLA, D. OHRI. Chenopodium quinoa - an Indian perspective. Industrial crops and products, 23, 73-87 (2006).

6. M.C. GELY, E. M. SANTALLA. Moisture diffusivity in quinoa (Chenopodium quinoa Willd.) seeds: Effect of air temperature and initial moisture content of seeds. Journal of Food Engineering, 78, 10291033 (2007).

7. I. DINI, G.C. TENORE, A. DINI. Nutritional and antinutritional composition of Kancolla seeds: an interesting and underexploited andine food plant. Food Chemistry, 92, 125-132 (2005).

8. S. COMAI, A. BERTAZZO, L. BAILONI, M. ZANCATO, C.V. COSTA, G. ALLEGRI. The content of proteic and nonproteic (free and protein-bound) tryptophan in quinoa and cereal flours. Food Chemistry, 100, 1350-1355 (2007).

9. S.B. MATIACEVICH, M.L. CASTELLIÓN, S.B. MALDONADO, M.P. BUERA. Water-dependent thermal transitions in quinoa embryos. Thermochimica acta, 448, 117-122 (2006).

10. S. FAIRWEATHER-TAIT, S. SOUTHON, B. CABALLERO. Encyclopedia of Food Sciences and Nutrition. Academic Press: Cambridge, MA, USA (2003).

11. S.E. JACOBSEN. The worldwide potential for quinoa (Chenopodium quinoa Willd.). Food reviews international, 19, 167-177 (2003).

12. S.E. JACOBSEN. The situation for quinoa and its production in southern Bolivia: from economic success to environmental disaster. Journal of Agronomy and Crop Science, 197, 390-399 (2011).

13. CAPMS. Central Agency for Public Mobilization and Statistics, the consumption of food materials in A.R.E. Statistical yearbook (1998). 
14. H.B. IBRAHIM, M. AFAF, S.M. HEGAZY. II. Bioavability of iron of enriched bread diets with iron and amino acids. Egypt. J. Food sci. 20. No 2; 211-220 (1992).

15. A. ABOU-ZAID, S. EL-FAHAM, W. EMAM. Use of quinoa meal to produce bakery products to celiac and autism stuffs. Intern. J. Sci. and Res, 3, 1344-1354 (2012).

16. AOAC, Association of Official Analytical Chemistry. Officia Methods of Analysis of the Association of Official Analytical Chemists. 18 $18^{\text {th }}$ Ed. Washington, DC, USA (2005).

17. D. PEARSON. The Chemical Analysis of Foods. 7th edn. Edinburgh, London: Churchill Livingstone (1976).

18. J. MURPHY, J.P. RILEY. A modified single solution method for the determination of phosphate in natural waters. Analytica chimica acta, 27, 31-36 (1962).

19. S. SADASIVAM, A. MANICKAM. Determination of total sugars, reducing sugars and amino acids, Agric. Sci., Wiley Eastern Limited, New Delhi, pp. 6 and 40, India (1992).

20. E. MILLER. Determination of the tryptophan content of feedingstuffs with particular reference to cereals. Journal of the Science of Food and Agriculture, 18, 381-386 (1967).

21. AACC, American Association of Cereal Chemistry. Approved Methods of the American Association of Cereal Chemistry. 10 $0^{\text {th }}$ Edition, St. Paul, Minnesota (2005).

22. A. EL-FARRA, A. KHORSHID, S. MANSOUR, A. ELIAS. Studies on the possibility of supplementation of balady bread with various commercial soy-products. 1982. In: Materials of $1^{\text {st }}$ Egypt. Conf. on Bread Res., Cairo. Pp. 9-23 (1982).

23. R.G. STEEL, J.H. TORRIE. Principles and Procedures of Statistics 2nd Ed. pp. 1200, McGraw-Hill, New York, USA (1980).

24. M. JANCUROVÁ, L. MINAROVIČOVÁ, A. DANDAR. Quinoa - a rewiev. Czech Journal of Food Sciences, 27, 71-79 (2009).

25. M. BLASCO LAMENCA. Composición de la quinua cultivada en el Altiplano de Puno, Perú Chemical composition of quinua (Chenopodium quinoa) cultivated in the Puno highlands, Perú. Turrialba (IICA), 29 (3) 219-221 (1979).

26. A. HAREEDYLOBNA, A. MAHAFAUZESANAA, A. KAMEL. Soybean-Quinoa drinks from newly introduced quinoa varieties in Egypt. Egyptian J. of Nutrtion, 24, 125-160 (2009).

27. National Academies of Sciences, Institute of Medicine. Fruits and vegetables yield less vitamin A than previously thought; upper limits set for daily intake of vitamin A and Nine Other Nutrients, Press Release Jan. 9 (2001).

28. K. GESINSKI, K. NOWAK. Comparative analysis of the biological value of protein of Chenopodium quinoa Willd. and Chenopodium album L. Part I. Amino acid composition of the seed protein. Acta Scientiarum Polonorum. Agricultura, 10 (2011).

29. R. STIKIC, D. GLAMOCLIJA, M. DEMIN, B. VUCELIC-RADOVIC, Z. JOVANOVIC, D. MILOJKOVIC-OPSENICA, S.-E. JACOBSEN, M. MILOVANOVIC. Agronomical and nutritional evaluation of quinoa seeds (Chenopodium quinoa Willd.) as an ingredient in bread formulations. Journal of cereal science, 55, 132-138 (2012).

30. G.S. CHAUHAN, R. ZILLMAN, N.M. ESKIN. Dough mixing and breadmaking properties of quinoawheat flour blends. International Journal of Food Science \& Technology, 27, 701-705 (1992).

31. K.G. WAFAA, A. S. SHAMS. Quality characteristics of quinoa seeds (Chenopodium quinoa willd.) as an ingredient in balady bread. Egyptian J. of Nutrition, XXVII (3), 133-160 (2012).

32. C.E. WALKER, J.L. HAZELTON. Dough rheological tests, Cereal Foods World, 41 (1) 23-28 (1996).

33. N. ENRIQUEZ, M.A. PELTZER, V. RAIMUNDI, M.L. TOSI. Characterization of the wheat and quinoa flour blends in relation to their bread making quality, The Journal of the Argentine Chemical Society, 91, 47-54 (2003).

34. K. LORENZ, L. COULTER. Quinoa flour in baked products. Plant Foods for Human Nutrition, 41, 213223(1991). 